\title{
MILITARY TRADITIONS WITH SPECIAL REFERENCE TO SOUTH AFRICA
}

By Brig Dr J.H. Picard, SM*

\section{Preliminary Look}

Within any military community one finds particular traditions, customs and ceremonies, the origin of which is often shrouded in the mists of antiquity. Even the origin of certain often used terms, so specifically martial and peculiar to the military, is generally quite unknown. This is a pity as such terms are a way of communicating to the soldier that

(a) he is not alone but a member of an illustrious group,

(b) he is duty and honour bound to uphold the fine traditions of the group to which he belongs,

(c) he is justly proud of belonging to such a unit for this also raises his self-esteem,

(d) it is more frightening to live having failed the unit or one's comrades than to lay down your life in the knowledge that you have defended the honour of your country, your unit and yourself,

(e) such terms contribute to effective teamwork and the esprit de corps so important in the military.

Traditions, then, inspire comradeship, pride, love, courage and discipline. Small wonder that their absence could lead to a disaster. In Military Manpower (1981) Canby attributes the poor discipline of USA soldiers in Vietnam (as compared with the British soldier in Ireland) to the abolishment of the regimental system with its focus on traditions.

According to Deon Fourie (Militaria, 1981: $35-37)$ the most general traditional customs recognised today in the SA Defence Force such as colours, retreat ceremonies and colours parades, military funerals, military weddings, etiquette and mess traditions and usages all originate overseas, most of them in Britain. He does not see any surviving signs of the Dutch influence in the Cape or in the Transvaal and Orange Free State republics. Despite the efforts made over a period to discontinue such British military customs, they are part and parcel of the SA Defence force.
Yet the Dutch contribution to British military customs was considerable, particularly in the time of the involvement of British soldiers in Europe first in the Netherlands against Spain and later against Louis XIV of France. In Elizabethan times and from 1572 British soldiers went to the Netherlands in increasing numbers to fight for Dutch independence. From 1689 to 1697 the British Army was again involved in the Netherlands and again during the Spanish War of Succession (1700 to 1715). There were even regiments formed in the Netherlands which went over to Britain later. The most well known of these regiments, says Fourie (1981) were the so-called "BUFFS" (83rd Foot Regiment) which initially in 1665 was called "The Holland Regiment".

During this period the Dutch contributed to British military customs and traditions. Prince Maurits van Nassau taught them to drill as tactical movements and various ceremonial usages still used in the RSA today originated from that period: colours parade, retreat, Tattoo which was anglicised from the Dutch Tap toe (doe de tap toe). So many of the British customs originated in the Netherlands and elsewhere on the European continent in those years that it is difficult to distinguish them from those of other European countries. The drum beats from the 16th century "landsknechten", the bugle signals originating in France in 1591, and even the "Last Post", which referred to the last guards set out to relieve those who had completed their terms of duty ("Auguet").

\section{Brief Survey}

Before moving on to a more detailed description of artillery traditions and the customs and details of some of our more well-known South African regiments, I will give a brief, albeit somewhat eclectic, survey of a few well-known traditions. For the details I am heavily indebted to Brig Deon Fourie. 


\section{Freedom of a City}

The custom of granting the "freedom of a city" to a regiment so that its troops can march through the city with drums beating, unsheathed colours and drawn bayonets was originally also intended for recruiting purposes. The drums were beaten to draw the public's attention and the colours were unfurled to show that the recruiting was for the King's service. Both in the old Roman armies and in the early British armies specific regulations applied as regards entry to a city. After 1842 it was, for instance, necessary for a military detachment to obtain the mayor's prior permission before crossing the city's boundaries and only some regiments were granted this privilege. Freedom of entry into a city or town granted to a military unit or formation is a traditional privilege and should be treated with the greatest respect although there appears to be some connection between that privilege of "freedom of a city" and honorary citizenship of a city/town.
When 7 Medium Regiment received the Freedom of Benoni in August 1981, they draped an artillery flag over the breech of each gun. This has become standard practice when their guns are on ceremonial parade.

\section{Regimental Colours}

The granting of regimental colours is a most important occasion perhaps best illustrated by Prince Alfred's Guard (Port Eliabeth).

The Guard's colours were presented in 1876 on the Port Elizabeth Cricket Ground. The Battalion headed by the band marched from the Donkin Reserve and formed up to make three sides of a hollow square. The drums were piled in the centre with the cased colours resting against them. The Chaplain to the Corps consecrated the colours which were then handed (the Queen's Colour by Captain Stewart, and the Regimental Colour by Capt Kirkwood) to Mrs

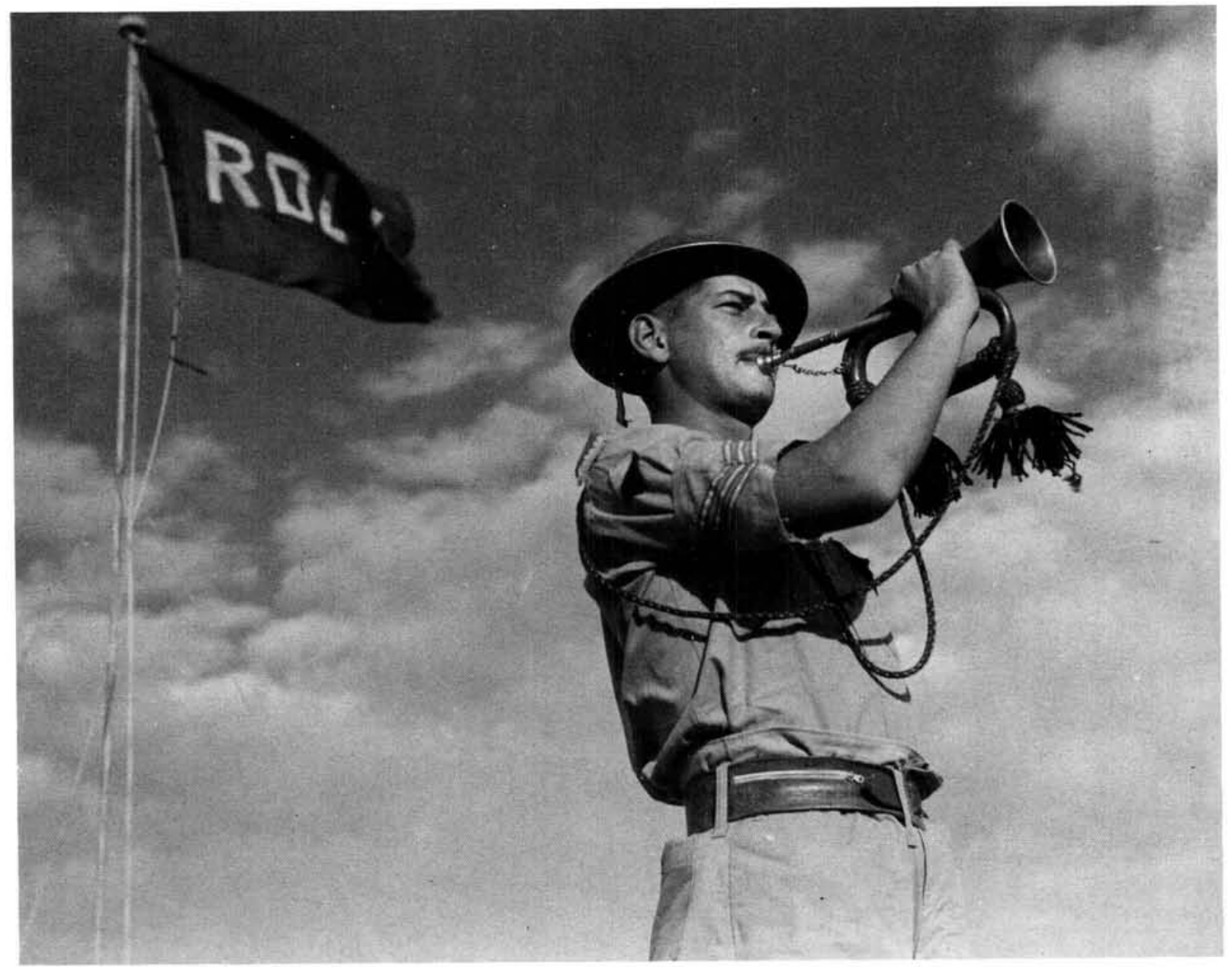

The last post blown on a bugle during General Dan Pienaar's funeral in 1941 by a bugler of the RDLI Regiment. (Photo E 1943: S.A. National Museum of Military History) 


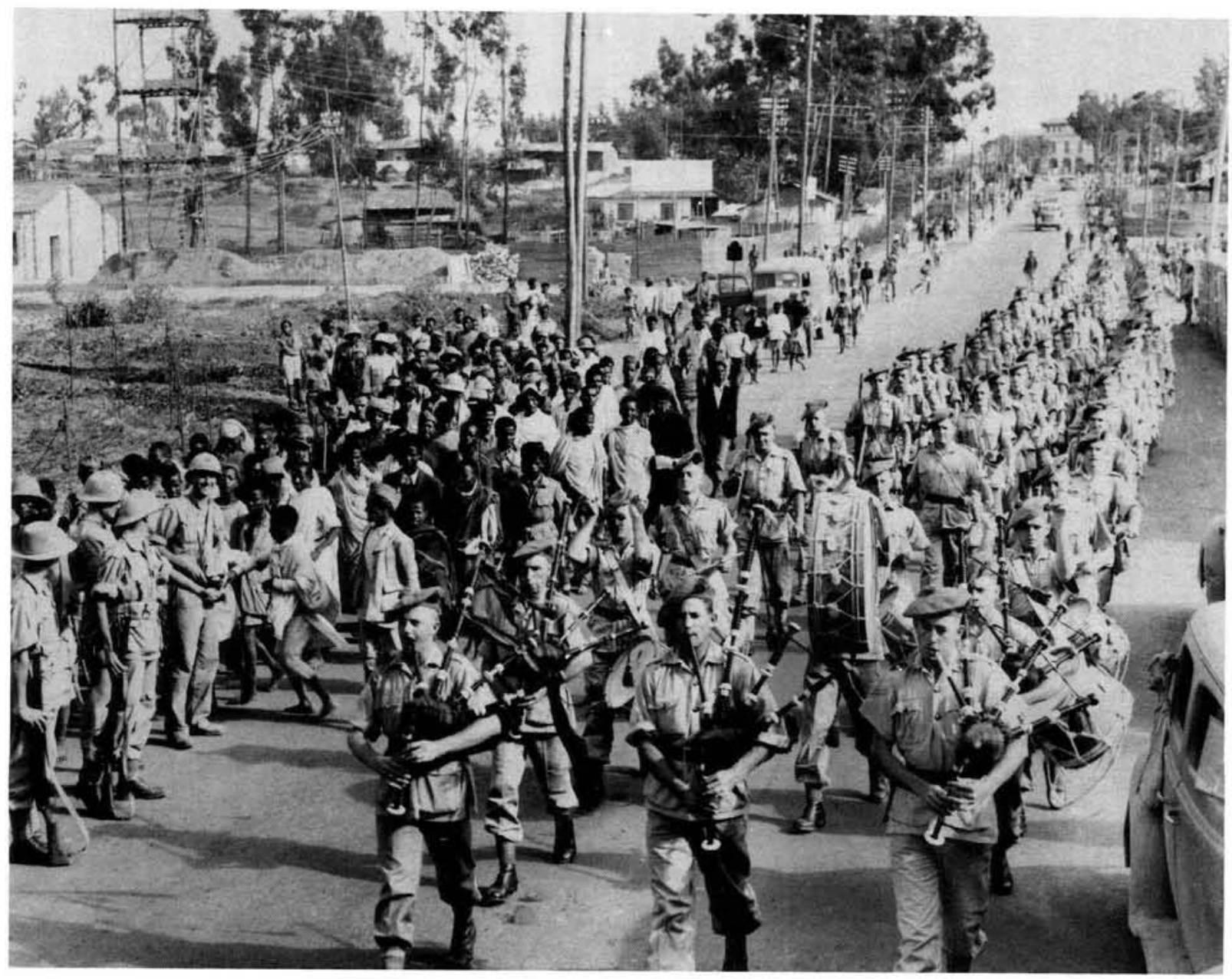

South African troops marching through the city of Addis Ababa.

(Photo EA 642: S.A. National Museum of Military History)

Wylde, who in turn handed them to lieutenants Deare and Morris, who knelt to receive them. Line was reformed, and the colours were trooped and received with presented arms by the battalion.

The regimental colour itself was mounted on a pole with a gilded spearhead, from which were suspended two heavy bultion tassels. The field of the colour was of rich scarlet silk fringed with gold, and having the union in the corner. In the centre were the arms of the regiment and the Royal Arms and shield of Prince Alfred, worked in coloured silk anci gold, enriched by the garter. with the motto "Honi soit Qui mal y pense" (Evil to him who evil thinks), and having the letters V.R. in gold on either side, and the whole enclosed in laurel wreaths and surmounted by the Imperial Crown in gold, with the title of the corps underneath.

\section{Change-of-Command Symbols}

The crown and sceptre are the oldest symbols of authority to be handed over to a succeeding king. The most well-known military symbol of authority is the field marshall's baton. At symbolic level it symbolises the authority of ruler or Commander-in-Chief. In the 14th century and thereafter the staff or baton represented legal authority. The field marshall's baton then is regarded as a variation of the royal sceptre which in turn harked back to the sacrificial axe. When Charles IX appointed his brother Henry (later Henry the Third of France) as general in 1569 he handed him a "baston" as symbol of his high office. In 1813 the Duke of Wellington captured the French Fieldmarshall's baton in battle. Thereafter the British Field Marshall received a similar baton from the hands of the King. This became the custom and was even extended to 
Naval flag officers. In the German Defence Force the epaulet of the Field Marshall comprises two crossed batons.

In South Africa the head of state will carry a traditional symbol on ceremonial occasions as does the Speaker of the Parliament, and mayors hand over their ceremonial chains to their successors. Many military units have their own symbols which are handed over to succeeding commanders during ceremonial parades.

\section{Medals}

The custom of presenting medals to worthy recipients originated with Alexander the Great and dates back to the third century $\mathrm{BC}$. The high priest Jonathan leading the Jews in a battle, rendered assistance to Alexander. To show his appreciation, Alexander presented him with a gold button, usually presented to the King's generals as a token of esteem. This gold button was the earliest known medal, commemorating war service.

The earliest known medal struck for war service was awarded to the Englishman John Kindal in 1480 ; it is now in the British museum.

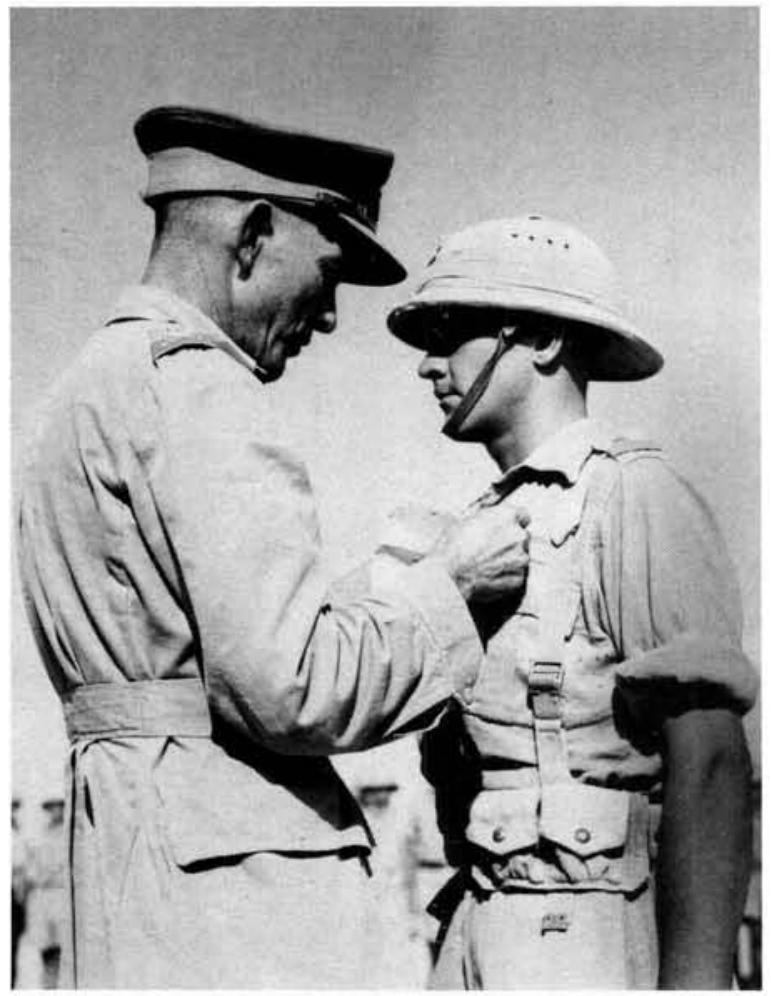

Maj Gen Dan Pienaar, D.S.O. and Bar, GOC 1st SA Div pins the ribbon of the V.C. on Sergeant Quentin Smythe at El Alamein.

(Photo E 1608: S.A. National Museum of Military History)
The decorations awarded today to fighting men probably have their origin in the badges or medals worn by the armies of England after the phasing out of body armour and prior to the introduction of distinguishing uniforms. Commanders rewarded soldiers for their performance on the battlefield by presenting their units with weapons worked in valuable metal and decorated with jewels. Heroes rewarded in this way exchanged their customary metal badge for a much coveted emblem. This basic action led to the present-day presentation of medals.

\section{Military Music}

The drum was the oldest military musical instrument and in the Roman armies it was beaten in cadence during the advance of cohorts and legions.

The Swiss soldiers in the 14th century marched in step to fife and drum and in the next century this was copied by the 'landsknechten' and adopted by other armies.

The Turks and Arabs developed full military bands and during the Crusades European armies came into contact with Saracen music. Minstrels brought back to Europe the new musical forms.

During the Renaissance military companies began to include musicians. The oboe replaced the drum and trumpet as principal musical instruments during the reign of Louis XIV of France, marking the birth of modern military bands.

To these were added the bassoon, the trombone, horn and serpent, and during the next centuries the trumpet and clarinet were added. In 1840 Adolphe Sax produced the Saxophone and now military music was of age. Bagpipes were a Scottish and Irish regiments' addition.

\section{Naval Traditions}

\section{Death at Sea}

When sewing up the corpse in an old hammock or piece of canvas, it is usual to put the last stitch through the nose of the deceased. Apparently this was done to avoid any chance of lowering the body overboard whilst in a state of catalepsy for the shock of having a stitch passed through the nose would be sufficient to bring the patient 
back to life. It was customary for the man who sewed up the corpse to be paid a guinea a body (TMK 1986).

\section{Naval Officer's Sword}

During the crusades the sword was used as a religious symbol and these weapons doubled as crucifixes. A crusader kissed his sword hilt whenever unsheathing or sheathing it as a prayer to God for success in battle or thanking Him for a victory. This custom is still honoured today by bringing the hilt to our lips when drawing or returning swords on parade.

The ancient law amongst gentlemen, that a sword must never be defaced, stems from the sword's use as a sacred object. The SA Navy unfortunately had to break this strict rule when South Africa became a republic, and the crowns were ground off the hilts and blades. The SA Army, however, honourably discharged their swords from service and new ones were issued with a new pattern. Unfortunately Army Permanent Force members and Commandos no longer use swords on parade and even the famous Sam Browne belts were retired. As a result of the cut of the uniform jacket in 1974 the Sam Browne could not be worn so that it was excluded and the sword followed suit. However many traditional Citizen force regiments have retained their swords and Sam Browne belts.

In Europe swords appear to have been developed from the knife in Minoan Crete and Celtic Britain between 1500 and 1100BC, (Middle Bronze Age). Towards the end of the Bronze Age these swords were gradually supplemented by other types of swords such as the long "Halistalt" swords and the swords of the Swiss or Rhone Valley Type. In due course the steel and iron swords as we know them today evolved.

When Naval officers wear their swords in this modern space era, it serves as a reminder that this custom, originating in the first uniform sword introduced by the British Admiralty in 1801, indicates that the bearer is an officer.

\section{Gun Salutes}

Gun salutes had their origin in the years when it took a long time to reload guns. By firing all a fort's or a ship's guns on the arrival of a dignitary a commander rendered his unit defenceless in honour of the dignitary. Naval Gun traditions dictated that the weaker party was to salute the stronger one and foreign visitors were to salute the country that had jurisdiction over the waters a ship was entering.

It is said that Naval gun salutes are fired in uneven numbers of five or seven on account of an old Naval superstition. Old regulations stipulated that a ship must fire seven guns and a battery on land three shots for each of the seven. In this way the 21 gun salute developed which later on became the international convention for the highest national sign of honour. The Queens Regulations stipulate that all royal salutes comprise 21 gun salutes.

The gun salute when celebrating a victory or very important occasion originated in the early 15th century in Europe when King Maximilian I returned to Germany after a victorious campaign and the citizens of Augsburg wished to pay him an honorary gun salute of a hundred mortar shots and 101 shots were fired by mistake. This number was then retained.

In addition to the gun salute there are also the hand salute, sword salute, rifle salute and flag salutes.

\section{The Military Wedding}

The military wedding is like other weddings except that the officers in the bridal party are in uniform, and the bride and groom usually leave the chapel or church under the traditional arch of swords of a detatchment consisting of ten to twelve members.

Members of the SADF do not have to obtain special permission for the wearing of uniforms at a military wedding. The type of uniform worn will be in accordance with the kind of wedding planned - formal or informal.

The best man should not be of a higher rank than the groom and senior officers may be asked to participate in the arch of swords ceremony if too few officers of equal or lower rank are available. The officer in charge and his second in charge should not participate as this does not befit their status.

\section{ARTILLERY TRADITIONS}

The forerunners of the artillerymen ("gunners") of today were not soldiers at all. For nigh on a 
century the artillery developed as "something of a distinct entity, almost a separate force" (SADF Archives 3613). Artillery men over the ages developed a feeling of superiority for they served the Gun to which King Louis XV gave the proud title of "ultima Ratio Regum" (the Final Argument of Kings), an inscription borne on all French guns on his orders. For many centuries the gun was an instrument of war that provided firepower above and beyond the capacity of all other weapons, twenty four hours per day if necessary, and which could dominate the battlefield. Today guided missiles fulfil that role to a large extent but the artillery remains a vital tooth arm.

In France and England in the 13th century, the word artillery meant bows and arrows. After Roger Bacon (1214-1294) invented gunpowder, it was only in 1313 that a German monk, Berthold Schwartz, made the first gun with gunpowder as a propellant. These were called Vasi or Pot de fer, a vase-shaped receptacle into which powder was placed and from which an arrow was fired by means of a hot iron applied to a touch-hole. In the battle of Crecy in 1346 the English were described as using bombards which with fire projected little balls to frighten and destroy horses.

Typical of the method of manufacture of guns was that used for a gun made for Henry $\mathrm{VI}$ in 1440: 14 long bars in a circle like staves in a barrel (hence the word "barrel" applied to the piece) imperfectly welded together and strengthened by hoops of iron shrunk onto the staves. In 1939 an invention made it possible to cast a gun in one solid mass and then bore the chamber afterwards (hence the word "bore").

When guns could not be saved on the field of battle gunners rendered them useless to the enemy by driving a spike or wedge into the touch-hole or vent (spiked) so that the gun could not be fired and was thus completely neutralised. Today spiking the guns usually means ramming a shell into the mouth of the barrel and then firing a round.

Guns were originally named individually and according to size after all kinds of monsters. The mortar was, for instance, derived from the German "Meerthier" (sea-beast).

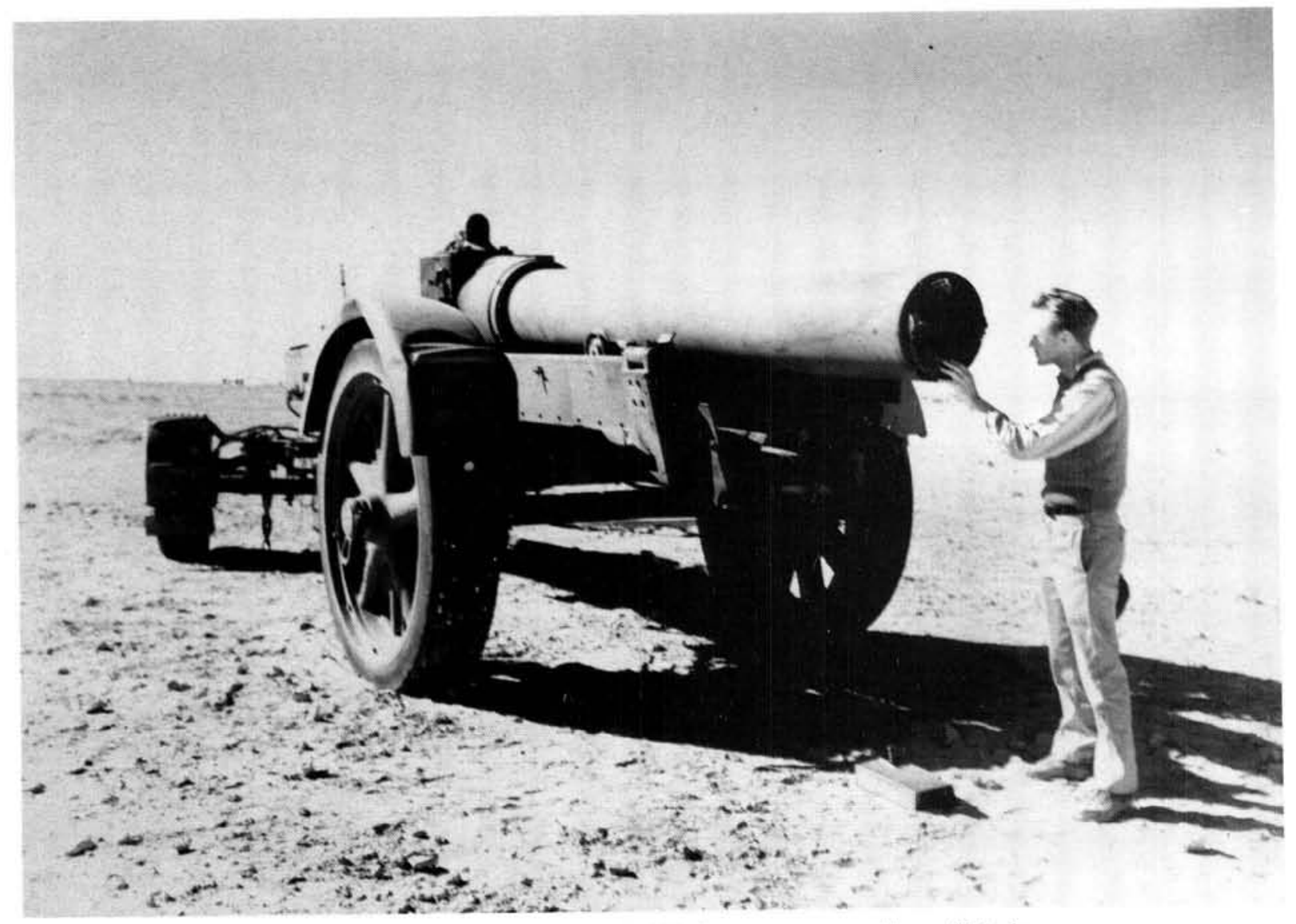

A 'spiked' German $210 \mathrm{~mm}$ gun of 1939 vintage seen near Mersa Matruh. (Photo E 1706: S.A. National Museum of Military History) 


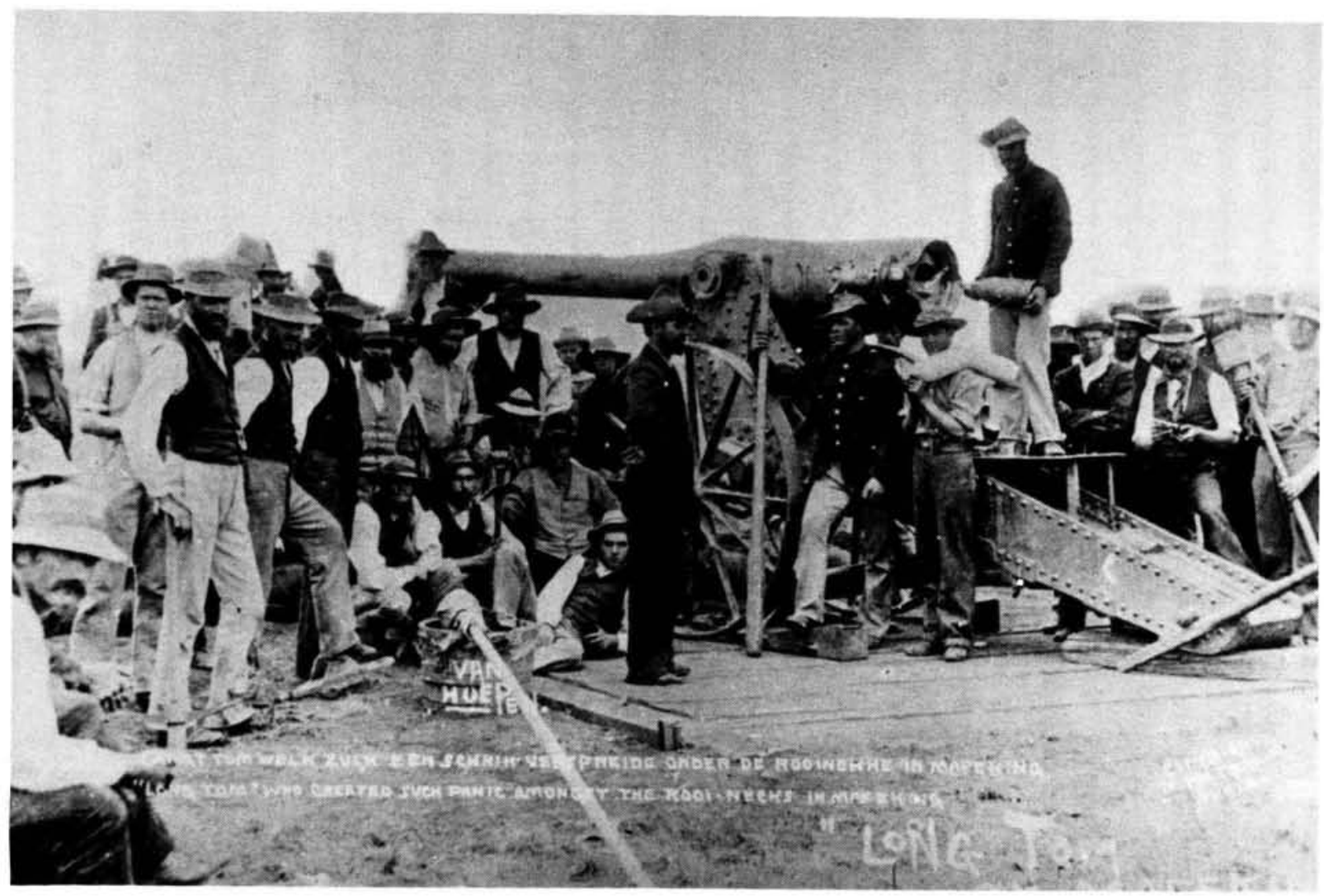

The 'Long Tom' used by the Boer artillery during the siege of Mafeking. (Photo: S.A. National Museum of Military History)

Heavy guns (bombards) in Germany gave way already in 1385 to lighter ones mounted on wood and supported by a fork, hence the word Hakenbüsche (corrupted by the English to Hackbutt, Hagbush and finally Harquebus). Later a stock was fitted to the piece to enable it to be carried by hand. So the rifle developed from the gun. The Howitzer derives from the German Haubitze, which came into use in 1750.

The artillerymen developed their own ranks. For instance, bombardier was created in 1686 and the bearers of the rank worked under the control of fire-workers (firemasters assistants) in specialized duty with mortars. Corporal was an artillery rank until 1920 below sergeant and above bombardier (the rank mattross was abolished in 1783.).

King Henry VII of England (1485-1509) formed the first permanent force of gunners when he appointed a master gunner and 12 paid gunners at the Tower of London. When artillery was required for a campaign, it was organised as a "Trayne" to which certain pieces of ordnance were allotted together with "Master Gunners", "Masters" and "Mattrosses", the latter being gunners' assistants. With the Trayne, whenever it went, there were many weapons following behind carrying all the equipment and comforts of home, including hired women. It is thought that the term "Son of a Gun" originated from this practice.

In Britain the Royal Artillery called itself "The Royal Regiment of Artillery" and its subunits (batteries) were grouped together as the need arose to form a regiment - hence the batteries perpetuate history, tradition and continuity of service.

South Africa's first permanent force in the days of the ZAR was the Republican State Artillery. South Africa has developed its own unique traditions. At one time two Regiments of Artillery existed; one was composed of Permanent Force batteries and one was composed of the batteries of the Cape Field Artillery (CFA), Natal Field Artillery (NFA), Transvaal Horse Artillery (THA) and from 1926 the first and second Oranje Vrystaat Staatsartillerie (OVSA). Only the PF regiment had a headquarters but from 1934 the South African Artillery Corps was formed "to consist of all units whether they be SAPF or 


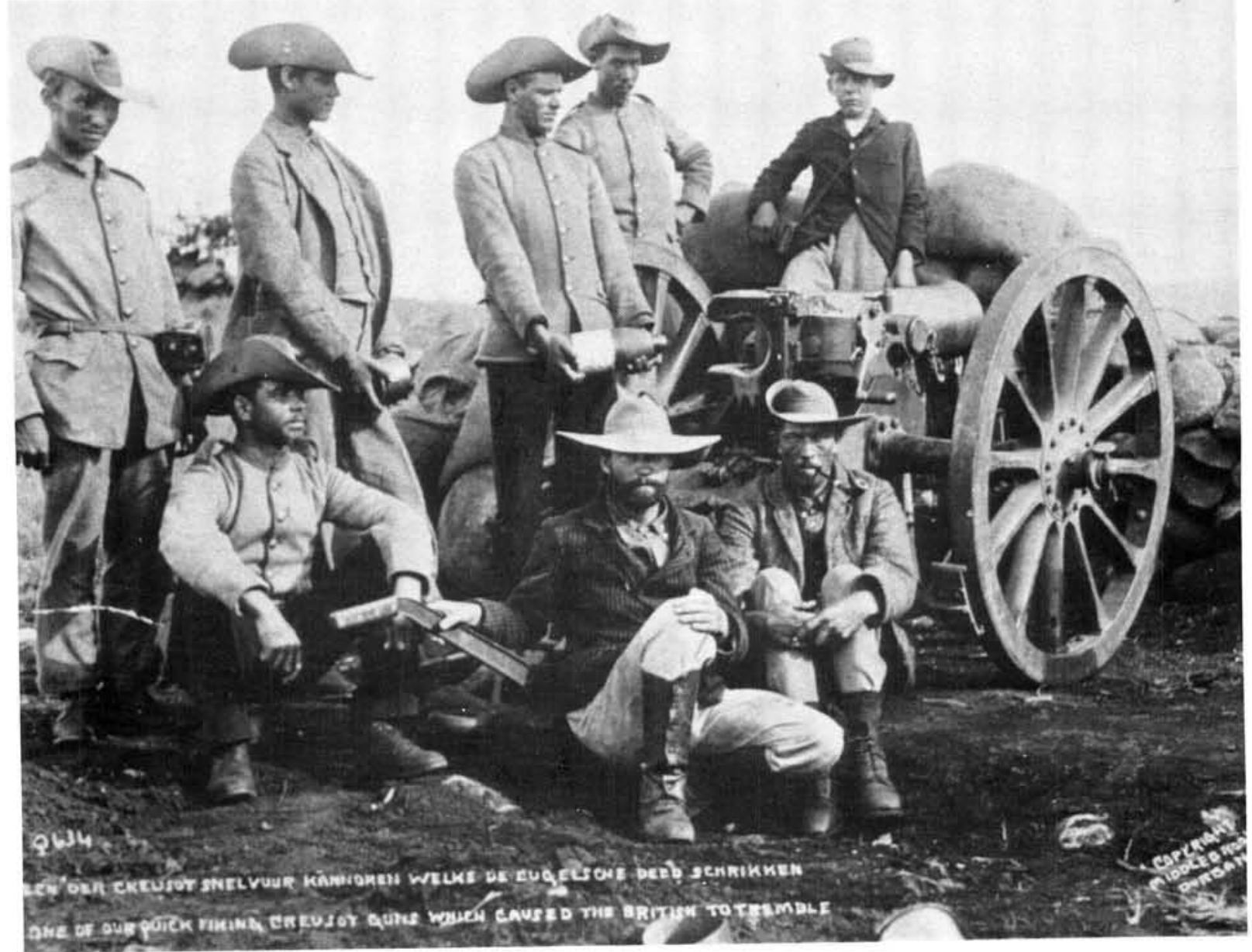

Creusot quick-fire gun used by the Boer forces. (Photo: S.A. National Museum of Military History)

ACF". From then on the South African Gunner tradition was born of individual regiments each with their own cap badges, but wearing the basic seven flame grenade as a lapel badge.

Gunners take great pride in themselves, their drills and their guns. There originated a definite drill laid down for working the guns in action, with thirteen words of command for the wielding of ladle and sponge in years gone by. A gun crew consisted of three men- the gunner, his mate (mattross) and an odd-job man who gave general assistance. The withdrawal of the least quantity of powder with the ladle after loading was esteemed a "foul fault for a gunner to commit" while the spilling of even a few grains on the ground was severely reprobated "it being a thing uncomely for a gunner to trample powder under his feet".

Owing to the important role played by the gunner in the war between the French and the English (1742-1748) he was accepted as part of the large brotherhood of the Army and in 1756 was granted the privilege of taking an ancient post of honour - the right of the line on all parades. This probably developed through the old practice of the guns always coming into action to the right of the infantry battalions, the latter always forming up for battle with the senior battalion or cavalry unit to the right and thus having more claim to the support of the guns.

By 1882 most artillery units wore their own individual battle honours which had become so numerous that in 1883 the word "UBIQUE" (everywhere) was used to replace them. At the same time, the privilege of bearing the Royal Arms over a Gun with the motto quo fas et gloria ducunt (whither Right and Glory lead) was granted by William IV and eventually replaced the original Board of Ordnance badge. The gun was of a design used at Waterloo and has remained the gunner symbol and cap badge all over the world in countries of many different nationalities. The South African Artillery motto 
worn on the Permanent Force badge since 1977 is "Primus incedere, exire ultimus" (first in, last out).

There is an artillery tradition in general use until fairly recently and in modified form still applicable to one South African unit. This is the practice of the No 1 Gunner to hit with his rammer any member of his gun detachment who failed to perform a duty satisfactorily. This traditional "chiding" is a relic of the days when the guns were swabbed out after each round fired to extinguish any smouldering powder remaining in the bore. One man placed his thumb over the vent when the gun was rammed to prevent the rush of air causing any remaining small spark to flare up and ignite the new powder charge. This was known as "serving the vent". Should the gunner fail to perform this duty the Number One would hit him over the head with a rammer. Sergeants Major of Cape Field Artillery each carry a ceremonial rammer as a reminder of this practice, instead of the usual pace stick. THA Warrant Officers carry a riding crop.

Unlike officers in cavalry or infantry regiments, where many years ago commissions were purchased, it was the practice to promote artillery officers from the ranks because of the specialised knowledge required of them. Even in the 18 th century gunnery was a science and gunner officers had to be prepared for really hard study to acquire a grounding in many subjects: mathematics, ballistics and chemistry as well as man and horse management. There existed even into the early 20th century a rather broad prejudice against the artillery as a body of pampered specialists.

Artillery officers, unlike officers in cavalry or infantry regiments, generally looked after themselves instead of being served by servants or batmen. In the Citizen Force regiments after the last war, when the UDF (SADF) provided batmen, Gunner officers did their own polishing and washing.

The dangerous nature of the early gunpowder and the poor discipline leading to many accidents, caused gunners to maintain very strict discipline in their units. A tradition peculiar to gunners is that they never walk but always run, elbows bent and arms held against the chest.

\section{Artillery Colours}

The gun has become the symbol of battle. All bodies of fighting men have had some object, an eagle, a banner, or colours on which to rally. To carry the colours was an honour, to die in their defence was an honour, and to lose them a disgrace. Gunners feel the same about their gun and it must be prevented at all costs from falling into the hands of the enemy intact. Thus the guns became the standards or colours of artillery and should be treated in the same way as infantry colours. Troops on guard present arms whenever a troop of manned and dressed guns it towed past them.

No effort is too much in the duty of maintaining, changing, polishing and oiling the gun; even in the heat of battle the gunner will look after it and keep it clean, for to him the gun is the symbol of his superiority over all other corps in the service. South African gunners too; some regard it as their colour, others such as 4 and 14 Artillery Regiments and 1 Locating Regiment, have actually been presented with colours.

\section{The Gun Park}

Because of the respect with which the guns are treated, the gun park is regarded by gunners as the "holy of holies" to be kept clean and tidy at all times and in one South African unit the Gun Park is used for the unit's annual birthday church service.

\section{Trooping the Colours}

For ceremonial occasions gunners dressed their ordnance with snow white drag ropes, picks and shovels varnished, aiming posts painted and brasswork gleaming.

Trooping the colours was performed with full ceremonial on the Grand Parade, Cape Town, by the Cape Field Artillery, the infantry drill having been amended to allow for a larger colour party and for the impossibility of trooping the 13 pdr gun and limber through the ranks. This received full approval of chief of the Army and has now become standard drill.

\section{Lanyards on the Right Shoulder}

Gunners used to wear lanyards on the left shoulder with jack-knife on the end and housed in the top shoulder pocket. Major General Geoffrey White in command of the Depot Royal Artillery at Woolwich in the early 1920's noticed that recruits unskilled in rifle drill were apt, when ordering 
arms from the slope, to disarrange the lanyard as the rifle passed down the left shoulder.

It also shifted the bandolier. Hence, in 1924 he ordered lanyard and bandolier to be worn over the right shoulder. While the lanyard change was adopted by the gunners, the bandolier remained for it had to be altered by the saddler if so to be worn.

CFA's original colours were scarlet and blue and hence their members wear a lanyard of these colours, whilst NFA wear red and blue and THA wear a white lanyard. One or two other units wear blue and yellow, colours that were introduced into the Corps in the 1960's and have since largely disappeared. 7 Light Anti-Aircraft Regiment wear a turquoise and scarlet lanyard.

\section{Caps and Collar Badges}

All over the world gunner officers and warrantofficers wear black cap and collar badges. This is a symbol of the days when gunners were allowed to wear wooden or leather buttons because the gun powder continually blackened their brass buttons and badges. The grenade collar badge is also international and is worn by most artillery corps. The detail varies from country to country but the basic design is still the grenade.

South African gunners wear silver in common with the rest of the SADF but some, CFA and CGA as examples, continue to wear brass buttons while 2 Locating Regiment and Regiment Vaalrivier wear black grenades. In the volunteer units that existed before Union in 1910, it was a general principle that officers wore gilt badges and accoutrements and other ranks wore silver. This arrangement was retained to a degree in the THA where officers wear a black badge, non-commissioned officers wear silver and gunners wear a silver beret badge. Non-commissioned officers and gunners in the THA wear silver badges but the NCO's wear their badges on a red background. CFA members wear a bronze beret badge which caused much annoyance to a former Commandant General who insisted that it should be brass. However he admitted defeat after two almost disastrous confrontations. The cap badges had erroneously been issued by QMG in bronze and bronze the unit has decided they should remain (SADF Archive 3613).

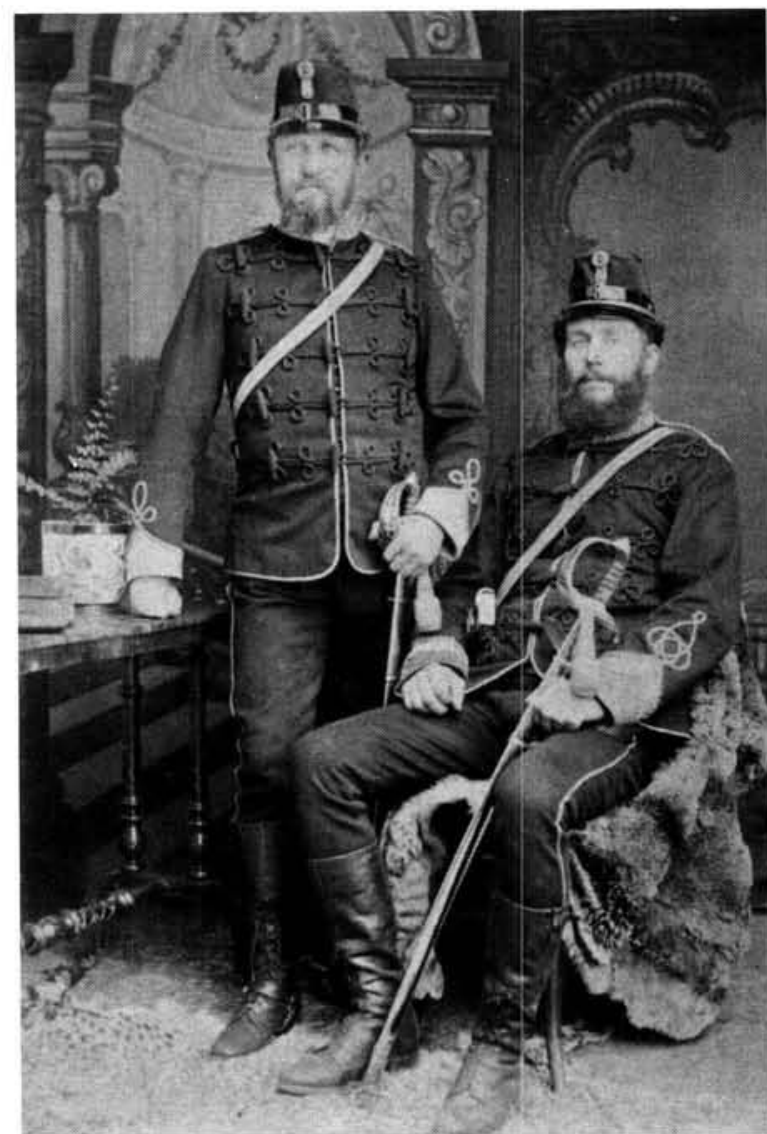

Traditional uniforms of the 'Staatsartillery' of the 'ZuidAfrikaansche Republiek' in 1899.

(Photo: S.A. National Museum of Military History)

The traditional colours of the artillery are Guardsman red and Oxford blue. The significance of this choice is not known but the earliest record of their use in gunner dress is in the inventory for the clothing of a "trayne" dated 1662. In 1699 in Flanders gunners were dressed in crimson coats faced with blue, wearing (in reverse order of prominence) the colours that have been retained until today ( $v o l$ 8: p 413).

\section{Battery Honour Titles}

Until February, 1940 batteries were identified as $A, B$ and $C$ and thereafter 1,2 and 3 , etc in accordance with the numerical designation of the regiment. For instance, batteries of Cape Field Artillery were 1st, 2nd and 3rd whilst the batteries of the 4th Field Regiment were numbered 10th, 11th and 12th Batteries and in 23 Field Regiment they were 67th, 68th and 69th.

In 1959 Cape Field Artillery gave their batteries honour titles in remembrance of the days when the unit was engaged in coastal defence as well as acting as a field unit. i.e. P (Amsterdam) bty, Q (Imhoff) bty, R (Wynyard) bty and, for a short 
time before the establishment again changed, S (Craig's) bty. All the names are those of actual batteries in the Table Bay defence where the unit manned the old Coastal guns until the newly formed Cape Garrison Artillery (CGA) took over in 1897. Transvaal Horse Artillery (THA) have retained the titles of 7 th, 8 th and 9 th Batteries of Second World War vintage and one of the new gunner regiments, 26 Field Regiment, has named their two senior batteries MARTIENIE and RAS after the two homemade gun built by Martinus Ras in the 1880's. This was as a result of the regiment firing a Salute at a memorial service to the gunmaker 100 years after the manufacture of the first gun ( $v o l$ 8: $p$ 413).

Natal Field Artillery have awarded honour titles to their batteries based on notable engagements in North Africa during the Second World War and have retained their numerical designations as well:

$$
\begin{aligned}
& 4 \text { ("E" Force) Battery } \\
& 5 \text { (King's Cross) Battery } \\
& 6 \text { (Rigel Ridge) Battery }
\end{aligned}
$$

and 7 Medium Regiment refer to their sub-units by the numbers 71,72 and 73 , in line with modern practice which follows the unit number.

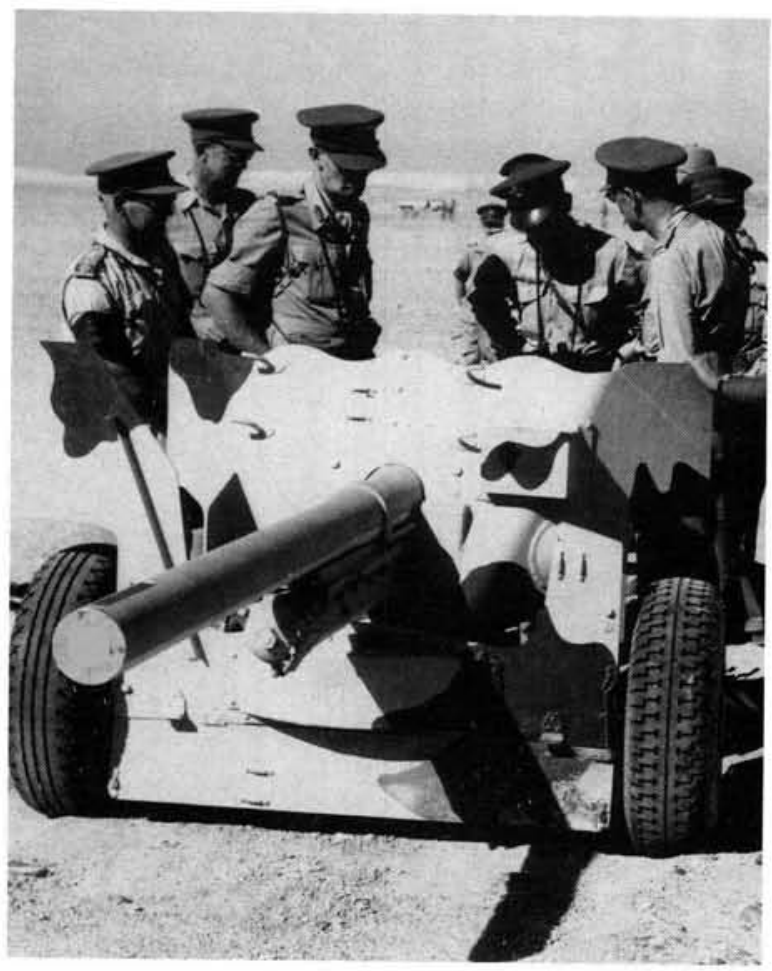

Major General A. Maxwell, MGRA, Middle East, discussing the new 6 pounder anti-tank gun with $\mathrm{Col}$ W.M. Randolph, of the US Ordnance when they and other senior officers visited the SA Artillery training wing in Egypt in 1941.

(Photo E 1703: S.A. National Museum of Military History)

\section{The Gunner and the Horse}

From the early days of artillery gunners depended on horses, although civilian drivers and hired horses were used to pull the guns until the formation in 1806 of the corps of Royal Artillery Drivers, which became part of the Royal Artillery after 1815. South African Artillery used to be always mounted and just before the outbreak of the Second World War the last horses were phased out. Because the artillery remained a mounted corps to the last, this gave rise to many South African traditions, such as the wearing of the Sam Browne belt by officers and warrant officers (some units continue to wear swords too); the wearing of a leather belt by NCO's (they only started to wear webbing during the last World War); the sword knot hanging free, and the use of the phrase "Wagon Lines" instead of a more modern term. In addition, undress blues are worn by some units where the jacket is cut in cavalry style while CFA's dress regulations include wearing overalls instead of trousers (overalls are narrow trousers, not quite skin tight, such as horsemen used to wear). The CFA and the THA order "Get mounted" and "dismount" instead of "embus" and "debus". Similarly the Transvaal Horse Artillery and the NFA continue even today with the custom of wearing box spurs with their undress blues and mess kit, a tradition that seems to have been dropped by CFA who, apart from being Coast and Field gunners, were for some years trained as horse artillery.

\section{Mess Traditions}

It is in gunner messes (some regiments already use the American term 'club') that a number of traditions and customs are to be seen, such as that of 4 Artillery Regiment who display their Regimental Colour during formal dinners. On these occasions they also place on the table before the most senior and junior Permanent Force Officer respectively, a model 9-pdr and a model 12-pdr gun.

7 Light Anti-Aircraft Regiment place their regimental port on the table bottled and undecanted, while THA members hammer the table by hand instead of indicating applause by clapping. Jugs of beer are also passed around the table after dinner and they also serve beer at breakfast the morning after a Mess evening ( $v o l$ 8: $p$ 144).

In both CFA and THA, newly joined or commissioned officers must purchase a beer mug on 
which is inscribed their name and date of commission or joining. These always remain in the Mess. In THA, however, the mug must be pewter and must have a glass bottom. On the death of an officer the bottom is broken with a special boot.

THA light an "eternal flame" before members at formal Mess dinners may sit. Cape Field Artillery always toast the unit by name, a practice dating back to World War II or even earlier. In 1960 they were renamed Regiment Tygerberg. Four years later they were re-named CFA but the toast continues to this day. In 4 Artillery Regiment a practice, which is sure to spread to other regiments, was commenced some few years ago of toasting "THE GUNS". Since 1975 at artillery dinners "The Guns" are toasted after the main toast.

\section{Social}

Since 1972, Gunners in South Africa have gathered socially once a month, usually in a day just after work during the second week. This has now become a tradition with such gatherings in for example Potchefstroom, Pretoria, Durban, at the Army Battle School and even Barberton. Such a gathering is referred to as a "Tiddler", the code word used for a Quick Fire Plan.

\section{Artillery Flash}

The well known zig-zag of the gunner symbolises thunder and lightning, perhaps as a result of the noise and flash of a gun, but it also relates to the story of the patron saint of all artillerymen, Saint Barbara.

\section{Honorary Appointments}

Since 1972 members of other SADF or Armscor that have rendered service to the South African Artillery have been selected and honoured by being appointed as a Honorary Limber Gunner. Only such members are entitled to wear the Gunners' Tie on Fridays.

\section{SAINT BARBARA: Patron Saint of Artillerymen}

Saint Barbara is the patron saint of artillerymen and her festival day occurs on 4th December. There are several legends surrounding this famous virgin and martyr.

In the early ages Santa Barbara was frequently invoked to grant safety during thunderstorms; and upon the invention of artillery was made the patron saint of the gunners. The connection between the lightning that killed Dioscorus and the zig-zag red line on the gunner's tie will be readily seen.

St Barbara was the daughter of a rich nobleman of Heliopolis in Egypt, martyred by her father about AD 303 for becoming a Christian. As he descended the mountain where he had cut off her head with his own hands, a "fearful tempest arose with thunder and lightning, and fire fell upon this cruel father and consumed him utterly, so that not a vestige of him remained". She is invoked against thunder and lightning, and all accidents arising from explosions of gunpowder. She was selected as patron saint for artillery because in early days cannon often exploded on discharge and hence artillerymen were always exposed to sudden death.

${ }^{\star}$ Brig Dr J.H. Picard SM is the Director of the SADF language Service.

\section{BIBLIOGRAPHY}

1. Adams, W.H.P. 1974. Famous Regiments of the British Army. East Ardley: EP Publ Co

2. Canby, S.L. 1981. "Military Manpower" in: Barlow, J.G. (ed) Reforming the Military. Washington DC: Heritage Foundation.

3. Chichester, W.M. \& G. Burges-Short. 1910 The Records and Badges of the British Army. London: Gale and Polden.

4. Fortesque, J.W. 1910 A History of the British Army VOL I London: Macmillan.

5. Fourie, D.S. 1981. "Waar ontstaan ons Militêre Tradisies dan?" in Militaria Vol no 1981. Pretoria: SADF.

6. Gorman, T.J. 1942. The British Army Today. London: Blackie

7. Neil Orpen. 1986. The Cape Town Highlanders 1885-1985. Cape Town: The CTH History Committee.

8. Perridge, F. 1939. The History of Prince Alfreds' Guard 1856-1938. Port Elizabeth: E.H. Walton

9. T.M.K. 1986. "Naval Customs and Traditions" in: Navy News Vol V no 7: Simonstown: SADF

10. Turner, E.S. 1956. Gallant Gentlemen - A Portrait of the British Officer 1600-1956. London: Michael Joseph.

11. Ultima Ratio Regum. Chapter 20 Artillery Traditions". Pretoria. SADF Archive no 3613. 